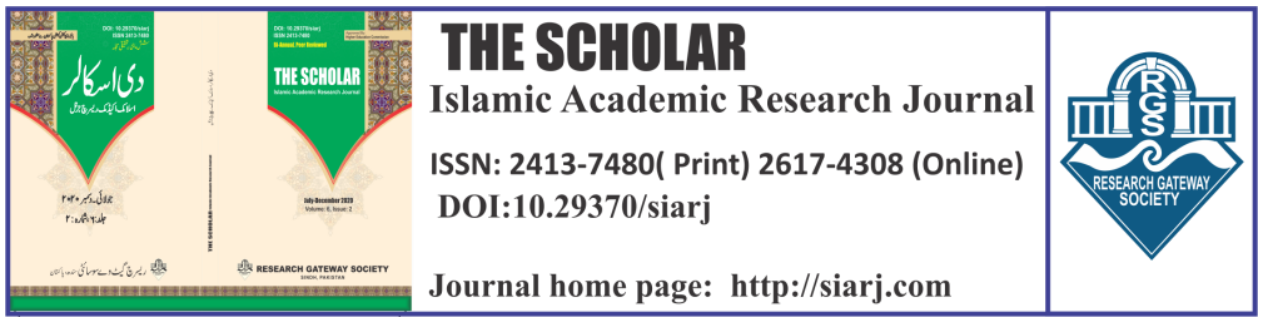

\title{
ETHICAL VALUES AND EDUCATION: AN ANALYSIS IN PERSPECTIVE OF ISLAMIC ETHICS
}

1. Syed Abdul Ghaffar Bukhari

Associate Professor, Department of Islamic Studies, National University of Modern Languages, Islamabad

Email: sagbukhari@numl.edu.pk

ORCID ID:

https://orcid.org/0000-0001-6531-6565
2. Munazza Sultana

Assistant Professor, Department of Islamic Studies, National University of Modern Languages, Islamabad.

Email: munazah@gmail.com

ORCID ID:

https://orcid.org/0000-0003-0710-5238

To cite this article:

Bukhari Abdul Ghaffar, Munazza Sultana. "ETHICAL VALUES AND

EDUCATION: AN ANALYSIS IN PERSPECTIVE OF ISLAMIC ETHICS"

The Scholar-Islamic Academic Research Journal 6, No. 2 (Dec 21, 2020): 1-29.

To link to this article: https://doi.org/10.29370/siarj/issue11ar1

\begin{tabular}{|c|c|}
\hline Journal & $\begin{array}{l}\text { The Scholar Islamic Academic Research Journal } \\
\text { Vol. 6, No. } 2 \text { ||July-December } 2020 \text { || P. } 1-29\end{array}$ \\
\hline Publisher & Research Gateway Society \\
\hline DOI: & 10.29370/siarj/issue11ar1 \\
\hline URL: & https://doi.org/10.29370/siari/issue11ar1 \\
\hline License: & Copyright c 2017 NC-SA 4.0 \\
\hline Journal homepage & www.siarj.com \\
\hline Published online: & $2020-12-21$ \\
\hline
\end{tabular}

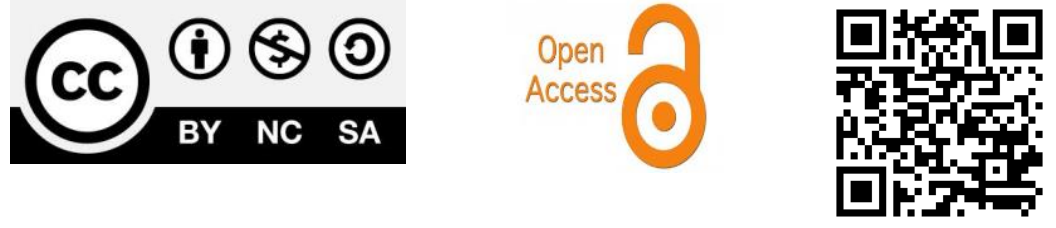


THE SCHOLAR (July- December 2020)

\title{
ETHICAL VALUES AND EDUCATION: AN ANALYSIS IN PERSPECTIVE OF ISLAMIC ETHICS
}

\author{
Syed Abdul Ghafar Bukhari, Munazza Sultana
}

\begin{abstract}
:
Today the contemporary world is facing social, moral, ethical, cultural and political challenges. One of the causes of social problems is lack of moral values in young generation especially the undergraduate students studying in universities. This results in unethical conduct, immoral behavior and actions such as robbery, sexual abuses, drug abuses, violence, and killing have been common among youth all over the world. Societies and nations with morality in youth are more likely to flourish compared to the societies characterized with unethical values. Since, the education is primary source for character building of youth and the contemporary education system of Pakistan is failed to produce ethical norms and values in the youth. The texture of social life is saturated with evil and threats, divorce, adultery, marital infidelity, family disorientation, child abuse and a high living cost which has led to the growth of social crime. Ethical principles are shattered to pieces with little or no social significance. Similarly, students studying in universities are lacking in moral values. Disrespect of teachers, parents, unethical attitude, dishonesty and bad conduct is very much common among university students now a day. Keeping in view this worst scenario, this study is aimed to highlight the unethical conduct of students and Islamic theory of ethics in order to find a solution to improve moral values of students in the light of Islamic teachings.
\end{abstract}


KEYWORDS: Ethics, Interplay, Ethical values, Islamic approach, Education

\section{ETHICS}

Ethics play a key role in establishing moral values and social norms in a society. Ethics is considered as an individual behavior, virtues of courage, potentials of justice, abilities of temperance, qualities of wisdom, and features of social freedom. Ethics is a rational process which enables individuals to explain their ethical decisions and moral opinions to others. Ethics is concerned with the process of finding rational justifications for our actions when the values that we hold come into conflict. Ethics is the most important demand in a religious and secular society and morality is the main focus of religious teachings after faith and worships. Ethics is believed to be the science of conduct, which includes human actions either right or wrong. There is a strong relationship between ethical values and societal values. Society develops rules and regulations to develop the ethical and moral values, which become the part of their culture. Ethics are relative to culture and emotional reactions. Ethical values are essential in daily life because these reflect human character, behavior and personality.

The term ethics is derived from Ancient Greek word (ethikos) from (ethos), meaning "habit or custom". ${ }^{(1)}$ In Arabic context, ethics is derived

${ }^{1}$ John S. Mackenzie, Hinds, A Manual of Ethics, Noble and Flridge, 1901, p. 1. 
from word "Khuluq" meaning "religion, character, disposition and trait". (2)

According to the Oxford Dictionary, ethics is defined as:

"The science of morals; the department of study concerned with the principles of human duty."(3)

Elaine Higgleton argues:

"Your ethical values are the things in life that you consider important or the principles and beliefs that influence your behavior."(4)

Alain Badiou defines ethics as:

"Ethics simply means protection from abusive interference. It amounts to an intellectual justification of the status quo. Operating exclusively in the realm of consensus, of self-evident; ethics is intrinsically conservative." (5)

From the above definitions, in Islamic tradition, term Akhlaq is

2 Ibn al-Asīr, al-Mubarak bin Muhammad, al-Nihayah F̄̄ Gharīb al-

Hadith Wa al-Asar, (Beirut: al-Makatabah al-Ilmiyah, 1979), vol. 2, p. 144.

3. J. A. Simpson and E. S. C. Wiener. The Oxford English dictionary, (Clarendon Press: Oxford, 1989), vol: 5th, ed 2nd, p. 421.

4. Elainne Higgleton, Anne Seaton, Chambers essential english dictionary, great britian at the university press, in Singapore by SNP Printing PTE ltd, p-1089

5. Badiou, Alain, Ethics, L'éthique. Paris, Hatier, 1993, p-2 
used to denote ethics; whereas Western scholars termed as habit and custom. Furthermore, it can be concluded that ethics is individual characteristics and traits which create the sense of right and wrong among the individuals of a society, which focus values and norms to socialize them and their environment. Ethics plays an important in developing the society and nations. Ethics considered as a line or margin between what is right and what is wrong. Usually, ethical values transfer from one generation to the next generation in the society. Every field of life requires good morality and ethical values including: business, traveling, marketing, sports, education, work, journalism and politics etc. Ethical values like honesty, trustworthiness, loyalty are required in every sphere of life and play a key role in developing individuals' personality in order to make them more reliable and responsible. Leslie Stephens rightly said:

"Morality is internal. The moral law and ethical values has to be expressed in the form "be this", not in the form "do this". The true ethics says "hate not", instead of "kill not". The only mode of stating ethics must be as a rule of character. ${ }^{,(6)}$

Ethics introduces a duty of moral development or behavior growth. Ethical values hold a central position in the mind of an individual and govern his/ her actions and deeds. Ethics encourages certain obligations like love and justice among families, nations, friends and peers. Ethical concerns make life civilized and socialized otherwise human commit

6 . Louis P. Pojman, An Introduction to Ethics, Wadsworth publications, 2005, P-165 
killing, robbery, and immoral activities. Therefore, ethics plays an important role for the survival of nations and communities and leads individuals towards humanity. Without ethical values and social norms human would become worse than animals. Ethical values provide enlightenment towards self-respect and self-dignity which promotes love and gentleness in the world. Ethics also help the individuals how to behave, interact and live in the society in a well-organized and welldisciplined manner. Consequently, ethical values and social norms are key elements to establish a healthy environment and a civilized society.

Ethics plays an essential role in all aspects of human life. In the field of education, ethics are significant because it is a basic and necessary step that individual takes from early childhood towards later stages of life. Essentially, the individual learns values and norms in an education system. Therefore, educational system produces opportunity for learning and teaching ethics. To highlight the significance of ethics, Aristotle rightly says:

"Educating the mind without educating the heart is no education at all."(7)

Consequently, ethical values help the individual to distinguish between right and wrong in educational system. It also helps in decision making and problem solving abilities. In the field of education, it is necessary that teachers and educators must follow values and norms as well as have complete knowledge of ethics because they have great

7 . Aristotle, "Nicomachean Ethics", Classics of Moral and Political Theory, ed. By Michael L. Morgan, Hackett Publishing Company: Indianapolis/ Cambridge. 1996, p. 855 


\section{A Study to Explore the Role of Leadership in Islamic Perspective}

Influence on children's moral development and character building.

\section{ETHICS AND EDUCATION:}

The education of ethics is necessary need of everyday life whether it is home or work-place. In the field of education, ethical values must be taught to raise the standards of individual life which may lead to the satisfactory family and social life. Essentially, ethical values and social norms improve interpersonal relationships and work performance. Sometimes, students may face ethical problems and moral issues in institutions and universities. Therefore, in the field of education, ethics and values are significant and play key roles in the development of students' character. Ethical values promote the moral standards of students by bringing internal changes. In education, ethics is necessary for the modification of students' character because they enter into the universities without basic values and morals. Therefore, they exhibit behavioral problems such as careless; aggression, violence, and moral corruption.

The objectives of the education in ethics are to improve goodness in individuals. Goodness might be expressed in various ways, including: work for the positive qualities in everyday life, live with an aim to boost what is useful for all concerned, adjust yourself to what is good for all around, represent the advantage of yourself and your condition, do and can be expected to amplify goodness for all, represent the advantage of the entirety. ${ }^{8}$

${ }^{8}$ Philippa Foot, Natural Goodness, clarendon press, oxford, 2001, pp, 81. 


\section{A Study to Explore the Role of Leadership in Islamic Perspective}

Ethics in education is concerning about what is useful for students and society. Our moral rules are continuously bordered and modified. They are not framed by some intellectual and incorporeal collectivity called "society" and then imposed on an "individual" who is in some way separate from the society. The basic teaching of ethics in education is to prepare the individuals obey rules where the rules compare inner good esteem framework, have been made decently, and are connected fairly. ${ }^{9}$

Each one of these objectives of education depends on the idea of reasonableness. As it were, morals are key to individuals' recognition of principles, and a propelled contemporary society that looks to argument consistence with its principles can't abstain from basing both the substance of its guidelines and the way they are made and connected on the sound moral rules that are trailed by that society. Constructing administrative and consistence frameworks in light of moral standards and practice will, along these lines, be basic for progress. Similarly, where activities are driven by exploitative, deceitful or willful thought processes, the recognizable proof of such activities and the burden of important and proportionate authorizations is required. ${ }^{10}$

Another ethical objective of education is respect. Respect has great position in our life. From our childhood are trained (one faiths) to respect our paternities, teachers, and heads, institute rules and circulation laws, domestic and cultural societies, others feelings and rights, our state's flag

${ }^{9}$ L Friedman, The Legal System: A Social Science Perspective Russell Sage Foundation, 1975, 105-13; 10 TR Tyler, Why People Obey the Law, Yale University Press, 2006, Pp,25 


\section{A Study to Explore the Role of Leadership in Islamic Perspective}

and heads, the truth and people's differing opinions. The fellowship of the Muslim Ummah isn't just an obvious and verbal fraternity - rather, it is a relationship of rights (upon each other) which has prerequisites and necessities (that must be satisfied) and subsequently, the Muslims must watch these rights in connection to each other.

\section{ETHICS IN ISLAM}

Islamic highly stresses ethics, values, and morals. In Islamic tradition, the term "akhlaq" is used to denote "ethics" and "ilm-al akhlaq" deals with "science of morals". Islam gives certain sets of values, norms, principles, and rules for individual and social life as well as to govern the society or nation. In contemporary world, nations have developed and set forth specific parameters for ethical values and ideal behavior. However, in Pakistan, there are worst conditions of ethical values and social norms. The main factor behind current conditions of Pakistani society is lack of Islamic knowledge and practice of the the teachings of Islam. Islam is considered as the complete code of life for Muslim in all aspects of life including moral values. In the entire human history, there found a great connection and relationship between worldly religions and ethics. Every religion and every Prophet greatly focused on ethics and morality.

Islam predominantly gives insight into ethics and morals that provide protection and safety to entire humanity and work for the welfare and reform of humankind. The teachings of ethics are considered as the basic teachings of Islam. For example, Allah has sent the last Prophet Muhammad $(\rho)$, and declared his moral at high standards, who reformed moral and spiritual life of the individuals during his regime. Allah Almighty says in the Holy Quran: 


\section{A Study to Explore the Role of Leadership in Islamic Perspective}

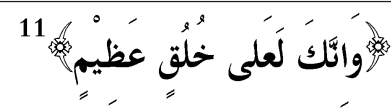

And indeed, you are of a great moral character.

The Prophets were sent for a particular religion and specific time period' but the Holy Prophet Muhammad $(\rho)$ was sent for the entire humanity and period of time. Allah Almighty declared the Prophet $(\rho)$ as the best example and perfect model for humankind. The Qur'an states:

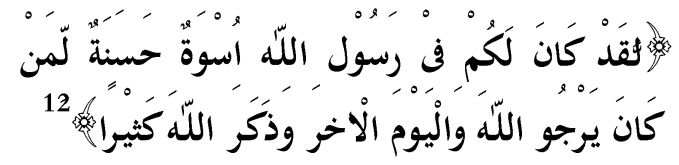

There has certainly been for you in the Messenger of Allah an excellent pattern for anyone whose hope is in Allah and the Last Day and [who] remembers Allah often.

The excellent model of the Prophet $(\rho)$ guided humankind in all aspects of life. Therefore, the Prophet $(\rho)$ recommended to be humble and gentle and do not indulge in false and unethical practices like robbery, theft, cheating, and interest, do not violate the Islamic rules and regulations, and do not harm the rights of other human beings.

Human beings are like a single unit in the world. It is the psychological and natural demand that individuals communicate and 


\section{A Study to Explore the Role of Leadership in Islamic Perspective}

interact with each other. Islam teaches the ways of interaction as explained in the Holy Qur'an:

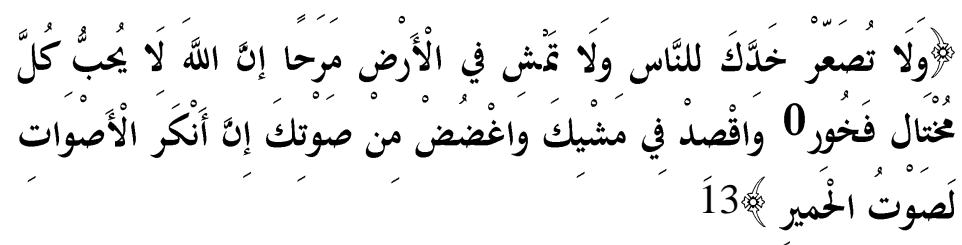

And do not turn your cheek [in contempt] toward people and do not walk through the earth exultantly. Indeed, Allah does not like everyone self-deluded and boastful. And be moderate in your pace and lower your voice; indeed, the most disagreeable of sounds is the voice of donkeys.

Likewise, Allah Almighty forbids about trembling of nations, fun and laughing, calling each other with bad titles or nick names and who does this would not be among Muslims and would be among wrongdoers. For example, in Surah Al-Hujrat it is mentioned as:

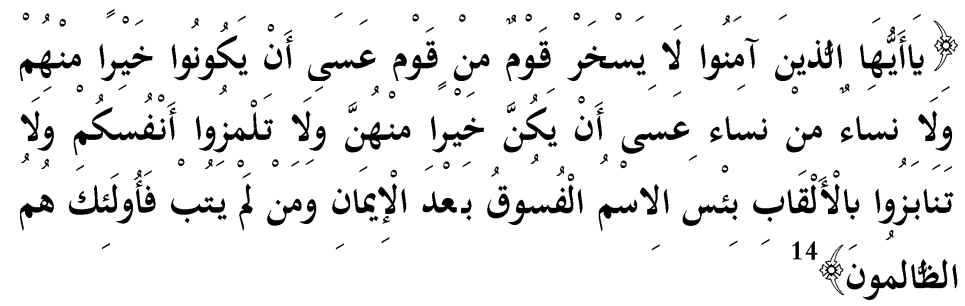

"O you who have believed, let not a people ridicule

13 .Luqman: 31/18-19.

${ }^{14}$.Al-Hujrat:49/11 
[another] people; perhaps they may be better than them; nor let women ridicule [other] women; perhaps they may be better than them. And do not insult one another and do not call each other by [offensive] nicknames. Wretched is the name of disobedience after [one's] faith. And whoever does not repent - then it is those who are the wrongdoer's.

The development and prosperity of any society depends on beliefs system and ethical values.

Addressing ethical values and morality was at the top of the Prophetic teachings. The Holy Prophet $(\rho)$ encouraged the ethical values and advised the individuals to interact with good morality. The Messenger of Allah $(\rho)$ says:

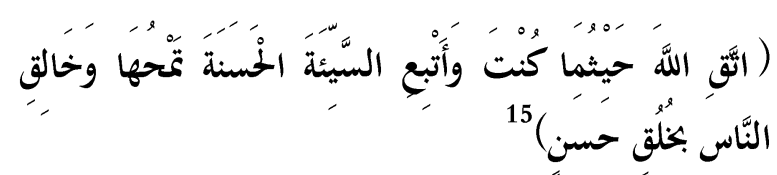

"Have Taqwa of Allah wherever you are, and follow an evil deed with a good one to wipe it out, and treat the people with good behavior".

This is what Allah Almighty says in the Holy Quran:

15. Jami-al- tirmzi Imam Abu `Isa Muhammad at-Tirmidhi, Darul Islam Riaz, publishers, 1404h Hadith No:1987 
The Scholar Islamic Academic Research Journal

Vol. 6, No. 2 || July -December 2020 || P. 1-29

https://doi.org/10.29370/siarj/issue11ar1

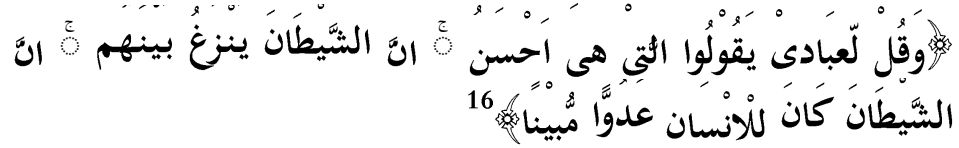

And tell my servants to say that which is best. Indeed,

Satan induces [dissension] among them. Indeed Satan is

ever, to mankind, a clear enemy.

Allah Almighty ordered the nations about ethical values in the following way in Surah Al-Baqarah:

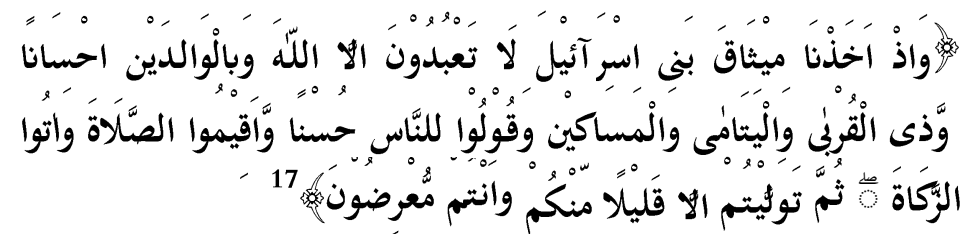

And [recall] when we took the covenant from the

Children of Israel, [enjoining upon them], "Do not worship except Allah; and to parents do good and to relatives, orphans, and the needy. And speak to people good [words] and establish prayer and give zakah. Then you turned away, except a few of you, and you were refusing.

Morality and ethics are the greatest virtue of this world. Using abusive language in communication and conversation causes is not allowed to Muslim believers. As the Holy Prophet ( $\rho)$ says:

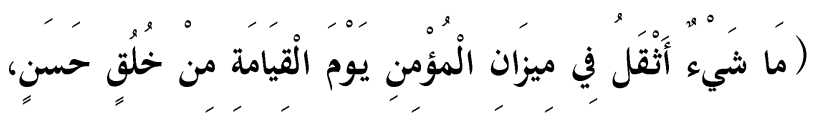

Al-Israh:17/53 _16

17 _Al-bqarah:2/83 


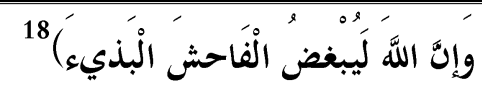

Nothing is heavier on the believer's Scale ón the Day of Judgment than good character. For indeed Allah, Most High, is angered by the shameless obscene person.

The concept of social ethics is of great important in the light of the Quran and Sunnah. Islam encourages people to be kind and good for others. This is a way through which Allah wipes off worries and removes the psychological distress from the society. As Allah Almighty says:

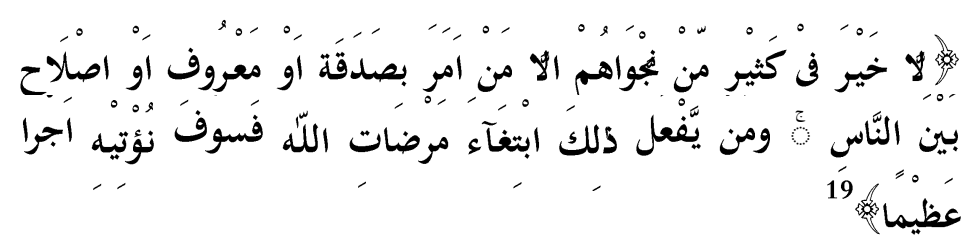

There is no good in most of their secret talks save (in) him who orders Sadaqah (charity in Allah's Cause), or Ma'roof (Islamic Monotheism and all the good and righteous deeds which Allah has ordained), or conciliation between mankind; and he who does this, seeking the good Pleasure of Allah, We shall give him a great reward.

The gentleness and morality are great blessings of Allah Almighty

18 . Jami-al- tirmzi. The Book of Rightenous and Virtues. Chapter: description of Ethics and morality. Hadith no:2002 19 _Al-Nisa :4/114 
on the individuals. Allah Almighty discusses good traits in the personality of Holy Prophet $(\rho)$ and advices him to show the gentleness, love and affectionate to other.

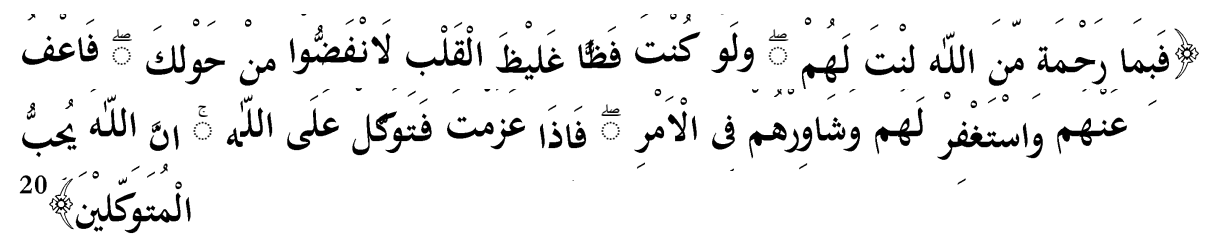

So by mercy from Allah, [O Muhammad], you were lenient with them. And if you had been rude [in speech] and harsh in heart, they would have disbanded from about you. So pardon them and ask forgiveness for them and consult them in the matter. And when you have decided, then rely upon Allah. Indeed, Allah loves those who rely [upon Him].

Islam establishes a world community by explaining the ethical values and moral norms. Ethics is the name of life and teaching of ethical values is the purpose of religion. Ethical values illustrate the purpose of human beings in this world. These values guide the individuals towards good attitudes and behaviors, because ethics deals with the spiritual aspect of Islamic civilization and culture. Essentially, the ethical values hold the position of spirit of life and existence in a Muslim society. The individuals can purify themselves by following Islamic ethical standards and values. Islamic ethical values provide purification in thoughts, feelings and emotions constantly.

\section{BASIC ETHICAL VALUES}

Traditionally, ethical values provide awareness of living in the 
The Scholar Islamic Academic Research Journal

Vol. 6, No. 2 || July -December 2020 || P. 1-29

https://doi.org/10.29370/siarj/issue11ar1

society. These values are considered as a form of social control and consist of a set of rules that must be obeyed by all citizens to maintain equilibrium state in the society. Following are the major ethical values mentioned in Islamic traditional approach:

\section{KINDNESS:}

Kindness is the most important component of the basic ethical values. It helps in socializing the individuals and developing social relationships. Islam has emphasized on this component. A verse in the Holy Quran says:

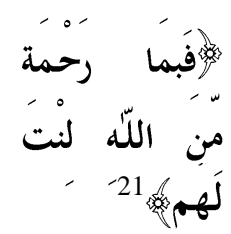

And by the

Mercy of

Allah, you

dealt with

them

gently.

Allah loves gentleness as the Holy Prophet $(\rho)$ says in a tradition:

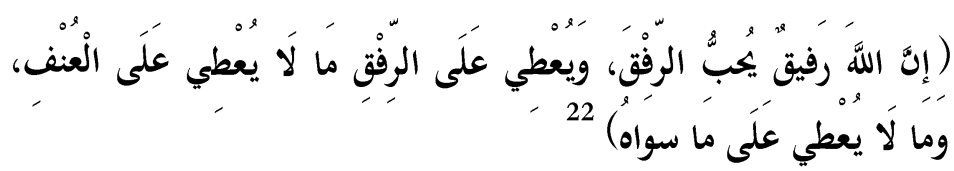

Allah is gentle and He loves gentleness, ánd He réwards

21 . Aal-e-'Imran: 159

Al HajajImam Abu Al Hassan, Sahih Muslim, The Book of Virtue, .22

Enjoining Good Manners, and Joining of the Ties of Kinshio, Darul Islam

Riaz, publishers 1404h, Hadith no:2593 
The Scholar Islamic Academic Research Journal

Vol. 6, No. 2 || July -December 2020 || P. 1-29

https://doi.org/10.29370/siarj/issue11ar1

for gentleness what is not granted for harshness, and He

does not reward anything else like it.

\section{HONESTY:}

Honesty leads the individuals to deal truthfully in all matters and eventually they avoid misleading or deceiving others. When the element of honesty is lost then society becomes a home of darkness and ignorance. Therefore, honesty is a key component of a society. Allah Almighty says in Quran:

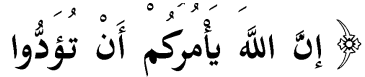

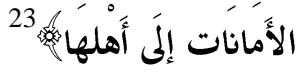

$$
\begin{aligned}
& \text { Surely, 'Allah } \\
& \text { commands you to } \\
& \text { deliver trusts to } \\
& \text { those entitled to } \\
& \text { them. }
\end{aligned}
$$

The Holy Prophet says:

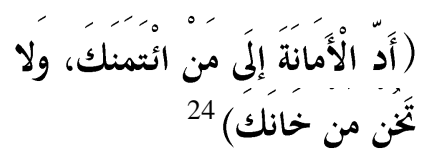

Fulfill the trust for the

one who entrusted you,

and do not cheat the

one who cheated you.

23 . Al-Nisa: $4 / 58$

24. Al-Tirmzi: Hadith no:1264 


\section{INTEGRITY:}

Integrity is an important element of the ethical values in the society. Therefore, this virtue should be practiced in the society for the welfare of mankind. The Messenger of Allah $(\rho)$ describes the importance of integrity in the following golden words:

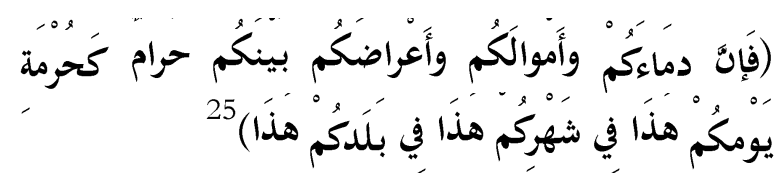

Your blood and yoúr wealth and your honor are sacred to one another, as sacred as this day of yours, in this land of you.

\section{TRUSTWORTHINESS:}

Truthfulness is an important ethical value. Trust is the basic element to build strong and healthy relationships in a society. Therefore, the individuals should make every possible effort to fulfill the promises and commitments they make. Islam greatly focuses on fulfillment of promise and establishment of trustworthiness, which is necessary to keep the security in society.

25. Sunan Ibn Majah, Ibn Majah, Darul Islam Riaz, publishers, 1404h Book: Chapters on Hajj Rituals, Hadith no:3171 
The messenger of Allah highlights the importance of honesty and truthfulness by saying:

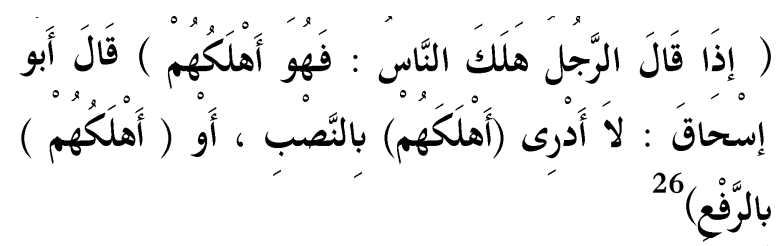

When a person says that people are ruined

he is himself ruined. Abu Ishaq said: I do not

know whether he said ahlakahum or

ahlakuhum.

The Prophet considers an individual among hypocrites if he/ she breaches promise:

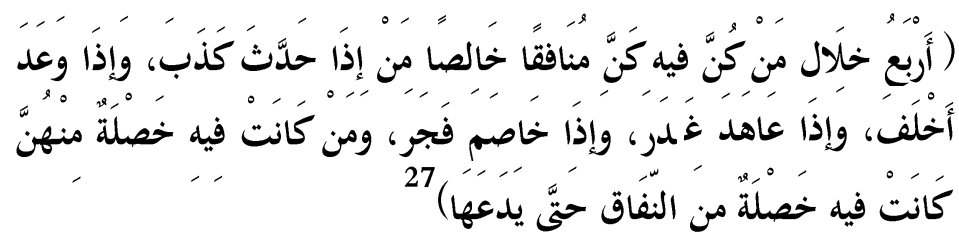

Whoever has (the following) four characteristics will be a pure hypocrite: "If he speaks, he tells a lie; if he gives a promise, he breaks it, if he makes a covenant he proves treacherous; and if he quarrels, he behaves in a very imprudent evil insulting manner (unjust). And whoever

Sahih Muslim, Muslim ibn al-Hajjaj, The Book of Virtue, Enjoining ${ }_{-}^{26}$

Good Manners, and Joining of the Ties of Kinshio, Hadith no:2623 27 .Sahih Bukhari, The book of al-jizya and the stoppage of war. Chapter, the sin of a person who makes a covenant and then proves treacherous, Hadith no:3178 
The Scholar Islamic Academic Research Journal

Vol. 6, No. 2 || July -December 2020 || P. 1-29

https://doi.org/10.29370/siarj/issue11ar1

has one of these characteristics has one characteristic of

a hypocrite, unless he gives it us."

Trust worthiness is important because it helps the individual to make a strong personality. Then individual is capable of arising the strong nation too.

\section{LOYALTY:}

Ethical values enforce the individuals to be loyal with others. Indeed, loyalty is important from personal to professional life in a society. Loyalty raises a deeper connection to the individual who practice this value. Allah $(\rho)$ highlights sad

$$
\begin{aligned}
& \text { They were not ordered but } \\
& \text { to worship Allah, making } \\
& \text { their submission exclusive } \\
& \text { for him with no deviation. }
\end{aligned}
$$

The messenger of Allah $(\rho)$ said:

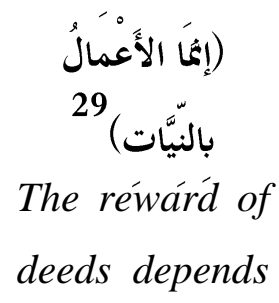

28 Al-Byena: 98/5

29 Sahih Bukhari, The book of Revelation, Hadith no: 1 


\section{JUSTICE:}

Justice is one of the significant ethical values. The justice and fairness means to restore the right of every rightful owner and behave with people justly; whether it is in personal life or social life. Muslims should be fair and just in all dealings of life. Fairness includes equality, justice and righteous in all matters. The Holy Prophet $(\rho)$ mentions the dignity of fairness and said:

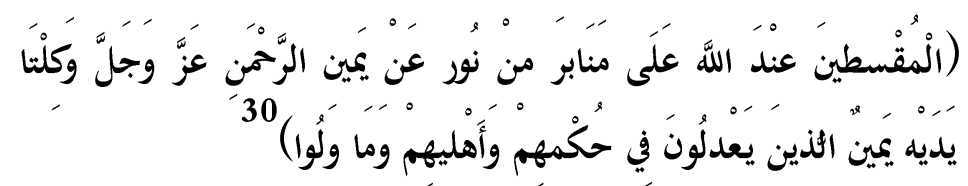

Verily, those who were fáir will be in the presencé of Allah upon pulpits of light, near the right hand of the Merciful, the Exalted, and both of His sides/ hands are right (being equal in honor); those who practiced justice in their rulings and with their families and in all that they did.

\section{CAREFULNESS:}

Ethical values enlightened the carefulness and protection of others. Helping others does not give any financial benefits, but it gives the inner

30 .Sahih Muslim, Muslim ibn al-Hajjaj, the book on government, , Darul Islam Riaz, publishers, 1404h.chapter,the merits of a just rulerand the demerits of a tyrant ruler, Hadith number:4721 
satisfaction and real joyfulness. The Holy Prophet $(\rho)$ described the reward of taking care of others in a Hadith:

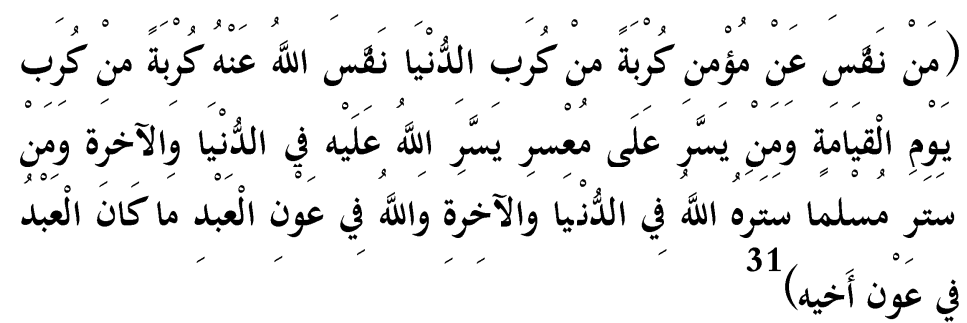

Whoever relieves the hardship of a believer' in this world, Allah will relieve his hardship on the Day of Resurrection. Whoever helps ease someone in difficulty, Allah will make it easy for him in this world and in the Hereafter. Whoever covers the faults of a Muslim, Allah will cover his faults in this world and in the Hereafter. Allah helps the servant as long as he helps his brother.

\section{RESPECTFULNESS:}

Ethical values demonstrate respecting human dignity, privacy, rights, and interests. Therefore, all people should be treated with equal respect and dignity regardless of sex, race or national origin.

Allah says in the Holy Quran:

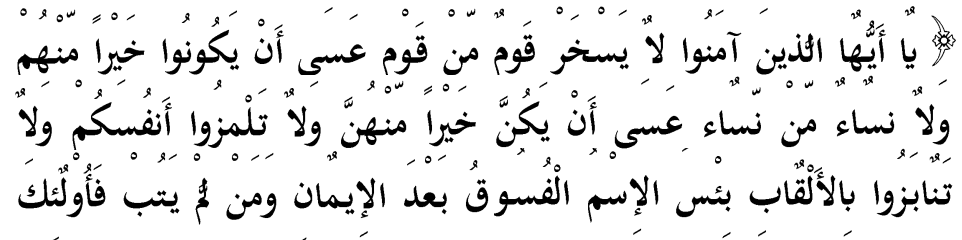

${ }^{31}$ Sahih Muslim, The book Remembrance of Allah, supplication, Repentance and seeking forgiveness, Hadith no: 6853 
"O' you who have true faith! Do not let men maké fun of other men - perhaps they may be better than the other (group of men). Also, do not let women make fun of other women, as it may be that they are better than the other (group of) women. Do not find faults in yourselves and do not defame one another by using bad names. How bad it is after having true faith that a person (does these acts) but does not turn in repentance (to Allah) so then surely it is these people who are the oppressors."

In this verse, there are three moral rules that the individuals who have true believed must watch are specified as being:

1. Indicating appreciation to the character or disrepute of a Muslim.

2. Disallowance of searching for shortcomings in other individuals.

3. The disallowance of utilizing or ascribing terrible nicknames to a believer.

In field of education role of teachers and religious scholars are the need of hour.

\section{OBEDIENCE:}

Ethical values recommend obedience of the laws, rules and regulations relating to the activities of daily life. An individual should obey the law of the land in which they used to live. They should not tell a lie, betray, or defraud anyone, nor can violate the rules and regulations. In 
general, Muslims are obliged to obey those in authority as long as they do not command to commit sins.

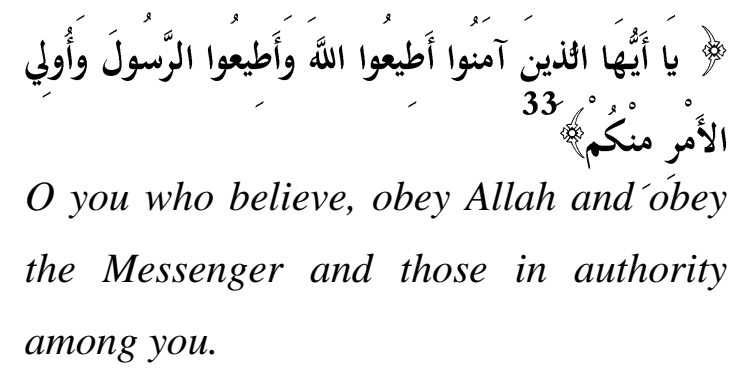

The Messenger of Allah, said:

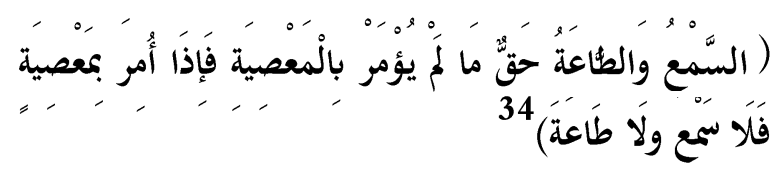

Listening to and obeying the leader is an obligation as long as he does not command disobedience to Allah. If he commands disobedience, then there is no listening to him or obedience.

\section{Responsibility:}

Ethical values recommend Muslims to be excellent in performing their duties and responsibilities. Everyone is responsible for his/ her duties and obligations in a Muslim society. The Holy Prophet highlights the responsibility of an individual in a Hadith and said:

33 Al-Nisa: 4/59

34. Sahih Bukhari, the book obedience, Obey the ruler as long as he does not impose sinfulness, Hadith:6725 


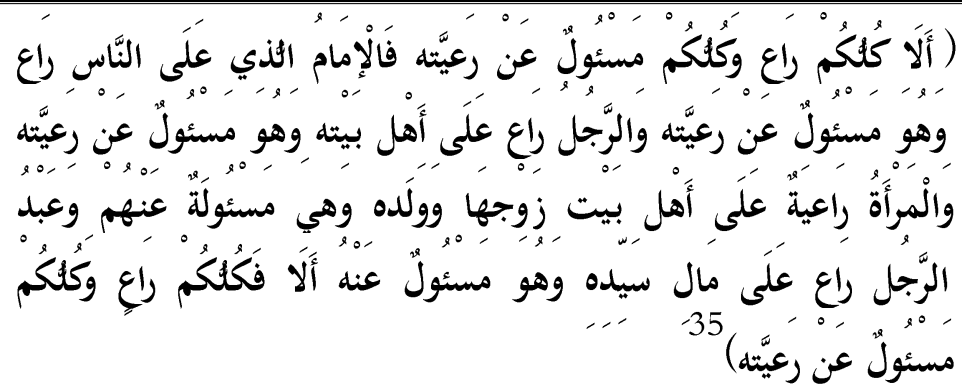

Every one of you is a shepherd and is respónsible for his

flock. The leader of people is a guardian and is responsible for his subjects. A man is the guardian of his family and he is responsible for them. A woman is the guardian of her husband's home and his children and she is responsible for them. The servant of a man is a guardian of the property of his master and he is responsible for it. No doubt, every one of you is a shepherd and is responsible for his flock.

\section{OPTIMISM:}

Optimism is the most important feature of ethical values. It plays an important role in human growth and development. Hope for the betterment effects all aspects of individual life. Therefore, optimism plays an outstanding role in the individual's progress as well as material and immaterial evolution. The Holy Quran states:

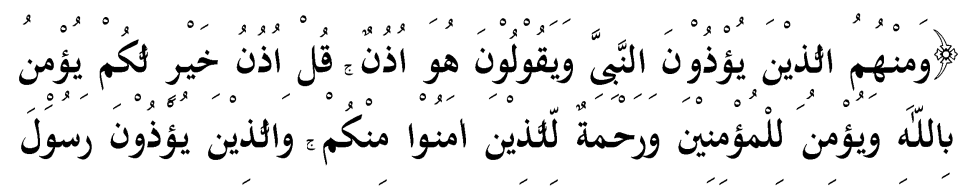

\footnotetext{
${ }^{35}$.Sahih Bukhari,book of judjement, Chapter obligations of Allah and his
} Prophet, Hadith No:6179 


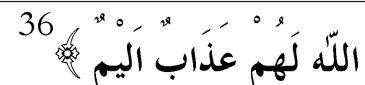

"Verse below shows that it is necessáry to respect faithful people and be optimistic toward them." Say: "He listens to what is best for you; he believes in Allah; has faith in the believers" and is a Mercy to those of you who believe." But those who molest the Messenger will have a grievous penalty”.

\section{ETHICS AND ROLE OF TEACHERS}

Teacher appreciate the importance of understanding the factors and contexts which are influencing the behavior, choices, lifestyles, health and welfare of children and young people and their families. They help children and young people to acquire and practice specific skills that support ethical values. Educational institutions are embedded with norms and customs in which teachers are conveyers. Teachers play vital role to help the children and young people to acquire and practice specific skills that support positive values. They implement strategies to monitor progress made by children and young people towards acquiring positive values. They develop a standard of personal life practices which will help to maintain his or her positive self-image in order to serve as a role model to students. Teacher helps the students to understand the character, traits and values. Students mostly idealize their teacher as a role model and copy their behavior. Teacher will have to develop a variety of means to morally stimulate adolescents and make them committed to moral action.

There is an interactive process between the teachers and students

$1619^{36}$. Al-Taubah: 
based on communicative approach. The principal of this approach is described in the Holy Quran as Allah says:

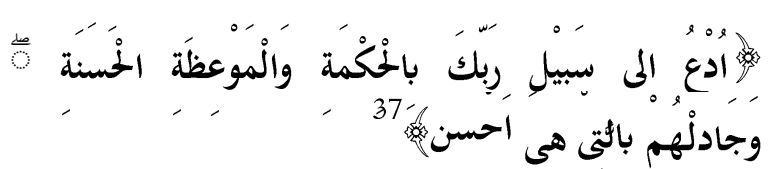

"Call to the way of your Lord with' wisdom

and beautiful preaching and argue with

them with that which is best".

In this verse Allah almighty explains the method of teaching that is suitable for the students. Use the social back ground, learning experience, apply instructional methodology as well as use the effective communication skills. Therefore, the teacher is main pillar in process of moral development in students so they must be equipped with certain professional skills, ethics and competencies for upbringing global innovations.

\section{ETHICS AND RELIGIOUS SCHOLARS}

Every religious scholar encourages the ethical and moral development in individuals. For this purpose they organize the programs, lectures and present the models to motivate the individual to follow the ethical values. It might be a tough assignment however it must be attempted, with the instructors occupied with showing Islamic Studies made cognizant that their undertaking is appointed as aides. They should be ingrained with a preacher soul to construct their students' character to shape a future society that is free from misuse, defilement and deception. 
The Scholar Islamic Academic Research Journal

Vol. 6, No. 2 || July -December 2020 || P. 1-29

https://doi.org/10.29370/siarj/issue11ar1

The religious scholars always presented unmatched model of moral and social values even in the modern world. Throughout the Islamic history, these scholars occupied a high social status. The first verse in the Quran encouraged learning and teaching. Those who possess knowledge and teach it to others are exalted and respected by Islam. The Quran says:

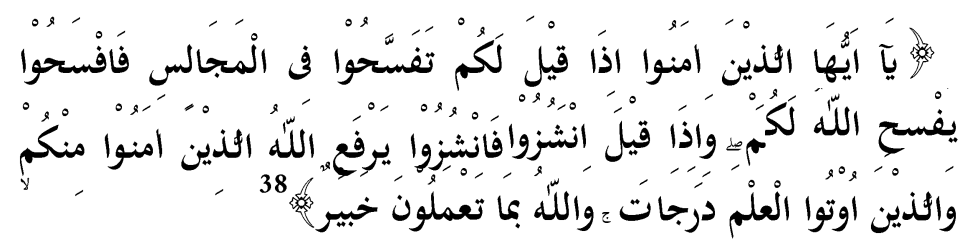

"O ye who believe! when it is śaid uńto you, Make roóm! in assemblies, then make room; Allah will make way for you (hereafter). And when it is said, come up higher! go up higher; Allah will exalt those who believe among you, and those who have knowledge, to high ranks. Allah is informed of what ye do."

Similarly, the Prophet Muhammad ( heirs of the Prophets by saying,

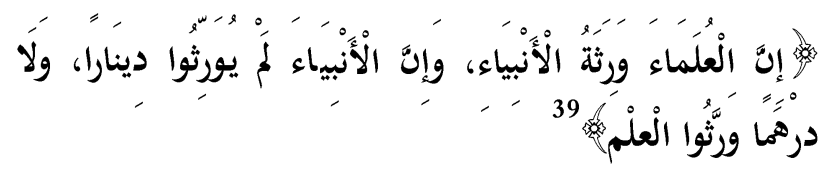

"The scholars are the inheritors of the

Prophets that the Prophets did not inherit

Dinars and not Dhirham but inherited the science"

38. Al-Mujadila:58/11 39 Sunan, Suliman Bin Ashas, , publisher, Al-Maktaba Tul Asariah Beruit, Hadith No.3641,p-3/317 
The learned ones are the heirs of the Prophets - they leave knowledge as their inheritance: he who inherits it inherits a great fortune." In Islam religious scholars correspond to the Ulama (the leaned personalities) and described as the Heirs of the Prophets. Transferring knowledge to others is believed to be worthwhile activity of teachers in Islamic Perspective and affirms the importance of teaching knowledge as great fortune.

Islam as revealed religion gives much importance to religious scholars. That's why a theses scholars have given a place in Islamic Perspective. They are regarded as heir of the Prophet. It is a selected rank given by the Almighty Allah to those who are pious and abide by the Islamic laws. They are becomes custodian of the Islamic values. They are responsible to transfer theses values to the next generations and the societies through preaching for the welfare of the mankind. Religious scholars have to be the role model for students as well as the community by setting high standards of living and interactions with people. So, religious scholars (Ulama) become a source of Islamic teaching as well as the interpreter of the contemporary situations.

It might be a tough assignment however it must be attempted, with the instructors occupied with showing Islamic Studies made cognizant that their undertaking is appointed as aides. They should be ingrained with a preacher soul to construct their students' character to shape a future society that is free from misuse, defilement and deception.

\section{Conclusion:}

The contemporary world is facing challenges i.e. social, ethical, moral, cultural as well as political in general. Islam creates a community by 
The Scholar Islamic Academic Research Journal

Vol. 6, No. 2 || July -December 2020 || P. 1-29

https://doi.org/10.29370/siarj/issue11ar1

defining ethical and moral norms. These values guide individuals about good attitudes and behaviors as ethics deals with spiritual aspect of an Islamic culture. Basic ethical values involve kindness, honesty, integrity, trustworthiness, loyalty, justice, carefulness, respectfulness, obedience, responsibility, and optimism.

The major cause of social problems is the lack of moral values being practiced by youth specifically the undergraduate students of universities. This results in unethical conduct, immoral behavior like violence, robbery, sexual and drug abuses, and killing among youth all over the world. The solution to this prevailing lack of moral values is the improvement of education. Education is primary source for character building of youth but it is seen that the contemporary Pakistani education system has failed to produce ethical norms and values among youth. It is necessary that the educational institutions must be embedded with norms and customs in which teachers are conveyers. Teachers may play an important role in helping youth to acquire and practice specific skills that support positive values. Along with them, religious scholars may also encourage ethical and moral development in individuals by organizing educational programs and lectures in order to motivate individuals in following ethical values.

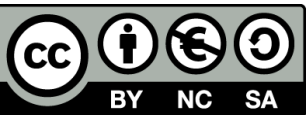

This work is licensed under a Creative Commons

Attribution-NonCommercial-ShareAlike 4.0 International (CC BY-NC-SA 4.0) 